\title{
PENERAPAN ALGORITMA EVEN-RODEH PADA APLIKASI KOMPRESI FILE GAMBAR
}

\author{
Agus Adi Pramadi ${ }^{1}$, Surya Darma Nasution ${ }^{2}$, Bister Purba ${ }^{3}$ \\ Program Studi Teknologi Informatika STMIK Budi Darma,Medan, Indonesia \\ Email: ${ }^{1}$ agusadipramadi@gmail.com, ${ }^{2}$ surya.darma.nasution1@gmail.com, ${ }^{3}$ bisterpurba91@gmail.com
}

\begin{abstract}
Abstrak
Beberapa file gambar ukuranya sangatlah besar. Sehingga membutuhkan kapasitas penyimpanan memori yang besar juga hal ini tentu banyak biaya yang harus di keluarkan untuk media penyimpanan tersebut. Dengan adanya ukuran file gambar yang sangat besar dalam proses pengiriman data file gambar bisa saja mengalami kegagalan karena media penyimpanan melebihi batas maksimum. Masalah di atas bisa diatasi dengan melakukan proses teknik kompresi file gambar yang besar menjadi ukuran kecil atau bisa mengurangi ukuran bit yang terdapat pada setiap file gambar sehingga menghemat wadah penyimpanan dan mempermudah proses perpindahan file gambar keperangkat media penyimpanan lainnya. Adapun Solusi dalam permasalah ini adalah bagaimana file gambar tersebut dapat dikompresi guna untuk mempercepat transfer dan penyimpanan file gambar. Kompresi file gambar bertujuan untuk mengecilkan atau mengurangi ukuran file akan tetapi tidak menghilangkan data informasi didalamnya. Dengan adanya teknik kompresi, data yang mulanya berukuran besar sehingga ukuran data dapat berkurang sehingga dapat menghemat ruang alokasi penyimpanan. Dalam penelitian ini menggunakan algoritma Even-Rodeh Code, dengan menggunakan metode tersebut hasil kompresi sangat baik dalam melakukan tramisi data dan pemindahan alokasi file gambar lebih mudah dan cepat.
\end{abstract}

\section{Kata Kunci : Kompresi File Gambar, Algoritma Event Rode Code}

\begin{abstract}
Some image files are very large in size. So it requires a large memory storage capacity too, this is certainly a lot of costs that must be spent on the storage media. With the existence of a very large image file size in the process of sending image data files can fail because the storage media exceeds the maximum limit. The above problems can be overcome by performing the process of compressing large image files into small sizes or can reduce the bit size contained in each image file thereby saving storage containers and simplifying the process of transferring image files to other storage media. The solution to this problem is how the image file can be compressed in order to speed up the transfer and storage of image files. Image file compression aims to reduce or reduce the size of the file but does not eliminate the information data in it. With the compression technique, the data was initially large so that the size of the data can be reduced so as to save storage allocation space. In this study using the Even-Rodeh Code algorithm, using the method results in very good compression in tramisi data and transfer of image file allocation easier and faster.
\end{abstract}

Keywords: Image File Compression, Event Rode Code Algorithm

\section{PENDAHULUAN}

Pada jaman sekarang ini kemajuan dibidang teknologi saat ini berkembang sangat pesat. Sehingga saat ini sangat membutuhkan alat pendukung untuk menjadi suatu hal yang sanggat tidak dapat dihindarkan pada saat sekarang ini. Pada saat ini kebutuhan dalam sebuah media penyimpanan menjadi hal paling utama karena akan menghasilkan sebuat data informasi. Dari informasi yang di hasilkan bukan hanya data seperti file text dan file audio, melainkan bisa menghasil sebuah data informasi file gambar.

Beberapa file gambar ukuranya sangatlah besar. Sehingga membutuhkan kapasitas memori yang besar juga hal ini tentu banyak biaya yang harus di keluarkan untuk media penyimpanan tersebut. Dengan adanya ukuran file gambar yang sangat besar dalam proses pengiriman data file gambar bisa saja mengalami kegagalan karena media penyimpanan melebihi batas maksimum. Masalah di atas bisa diatasi dengan melakukan proses teknik kompresi file gambar yang besar menjadi ukuran kecil atau bisa mengurangi ukuran bit yang terdapat pada setiap file gambar sehingga menghemat wadah penyimpanan dan mempermudah proses perpindahan file gambar keperangkat media penyimpanan lainnya.

Pada Hasil penelitian sebelumnya yang dilaksanakan oleh M A Budiman dan D Rachmawati pada tahun 2017 menyimpulkan bahwa Algoritma Even-Rodeh memiliki rasio kompresi dan penghematan ruang 66\%. Pada Bitrate Event-Rodeh lebih rendah dengan demikian Algoritma Even-Rodeh sangat efisiensi untuk melakukan kompresi file gambar. Konsep kerja teknik kompresi berdasarkan algoritma Event-Rodeh dilakukan dengan mengubah deretan nilai pixel citra, kemudian memanfaatkan deretan pixel yang di urutan bedasarkan frekuensi kemunculan nilai-nilai pixel pada citra yang akan dikompresi[1].

Pada tahun 2007 Didik Ardiyanto dan Bambang Hari Purwoto pernah meneliti tentang kompresi file gambar dengan format yang dikompresi adalah file gambar grayscale, dengan tujuan untuk memperkecil ukuran rasio file Gambar. Pada setiap format file gambar memiliki tingkat rasio kompresi yang juga berbeda-beda. Terutama dalam penyimpanan hasil gambar yang sudah dikompresi masing-masing file gambar pastinya sudah memiliki masing- 
masing rasio kompresi yang berbeda juga. Jadi hasil kompresi dari file gambar menggunakan algoritma Even-Rodeh relatif sangat kecil[2].

Dalam penelitian ini diharapkan dapat mengetahui bagaimana kinerja kompresi file gambar dengan mengunakan algoritma Even-Rodeh. Sehingga Didalam penelitian ini mampu mempelajari algoritma File gambar dalam mengkompresi data guna menghasilkan sebuah sistem yang dapat mampu memperkecil file gambar sehingga file tersebut lebih mudah diproses dalam pengalokasian penyimpanan awal kemedia penyimpanan yang lainnya.

\section{LANDASAN TEORI}

\subsection{Kompresi Data}

Kompresi Data adalah proses pemampatan ukuran dalam suatu data yang untuk menghasilkan representasi digital yang padat atau rapat namun tetap dapat mewakili kuantitas informasi yang terdapat pada data tersebut. Pada citra,vidio,dan audio, kompresi mengarah pada minimasi jumlah bit rate untuk mengrepresentasi digital. Pada beberapa literatur, istilah kompresi sering disebut juga source coding, data compression, bandwidth compression, dan signal compression[3]. Kompresi adalah mengecilkan atau memampatkan ukuran. Dalam penerapan didalam komputer, kompresi data adalah suatu teknik untuk memadatkan data sehingga hanya memerlukan ruang penyimpanan lebih kecil sehingga sanggat lebih efisien dalam menyimpan atau mempersingkat waktu pada saat pertukaran data[4].

\subsection{Teknik Kompresi}

Didalam teknik kompresi ada dua teknik dalam melakukan kompresi[3]

1. Kompresi Lossless

Pada teknik kompresi ini terdapat informasi yang didalamnya dapat menghasilkan citra yang sama dengan informasi pada citra awal. Citra hasil proses kompresi sebelumnya dapat dikembalikan secara sempurna menjadi citra asli, tidak terjadi kehilangan informasi,tidak terjadi kesalahan informasi. Oleh karena itu teknik ini bisa disebut juga error free compression. kompresi tipe ini cocok diterapkan pada berkas basis data (data base), spread sheet, berkas word processing, citra biomedis, dan sebagainya.

2. Kompresi Lossy

Kompresi data yang bersifat lossy mengijikan terjadinya kehilangan sebagian data tertentu dari pesan tersebut, sehingga dapat menghasilkan rasio kompresi yang tinggi. Apabila citra terkompresi direconstruksikan kembali maka hasilnya tidak sama dengan citra aslinya, tetapi informasi yang terkandung tidak sampai berubah atau hilang. Kompresi data lossy ini sanggat cocok jika diterapkan dalam penyimpanan data analog yang didigitasi seperti gambar,video, dan suara.

\subsection{Rasio Kompresi}

Rasio kompresi adalah menghitung kinerja dari repersentase data yang sudah dikompresi dan sebelum dikompresi. Secara sistemmatis rasio pemampatan data dituliskan sebagai berikut.

Rasio $=100 \%-\left[\frac{\text { hasil kompresi }}{\text { Data Asli }} \times 100 \%\right.$

Misalkan rasio kompresi adalah $10 \%$ artinya $10 \%$ dari data semula telah berhasil dimampatkan.

\subsection{Dekompresi}

Dekompresi merupakan proses mengembalikan data yang sudah terkompresi sebelumnya. data yang sudah dikompres dapat dikembalikan lagi ke dalam bentuk semula. Untuk dapat megembalikan data yang terkompres sebelumnya dapat dilakukan dengan cara yang berbeda seperti pada waktu proses kompres dilakukan. Jadi pada proses dekompres terdapat karakter header yang berupa byte-byte yang berisi karakter mengenai isi dari file tersebut[3]. Proses dekompresi adalah proses decoding terhadap citra terkompresi, proses decoding ini tergantung pada algoritma yang digunakan saat proses coding. Setelah decoding, dilanjutkan dengan proses transformasi balik (invers transformation) untuk menghasilkan subimage[3]. Langkah-langkah dekompresi untuk memperoleh file gambar semula adalah sebagai berikut:

1. Memasukan file gambar(image) hasil kompresi.

2. Pengurangan bit akhir ke string semula.

3. Menghitung bit sesuai dengan algoritma yang digunakan.

\subsection{Algoritma Even-Rodeh Codes}

Salah satu algoritma kompresi yang dikenal adalah algoritma Even-Rodeh Code. Algoritma Even-Rodeh Code adalah algoritma kompresi yang telah disebar luaskan oleh Shimon Even dan Michael Rodeh pada tahun 1978. Algoritma Even-Rodeh Code adalah algoritma kompresi data yang pengkodeannya menggunakan karakter-karakter dengan beberapa rangkaian bit yang mewakili karakter yang dibuat berdasarkan frekuensi setiap karakter. kode Even- 
rode hampir sama dengan kode Omega, Perbedaannya adalah bahwa panjang kode ditopang sampai panjang 3-bit tercapai dan menjadi grup kode paling kiri[5]. Berikut ini adalah langkah-langkah untuk mengkompresi file data menggunakan algoritma Even-Rodeh Codes [5]:

1. Masukan file data.

2. Melakukan pembacaan nilai karakter berdasarkan kemunculan frekuensi

3. Pembentukan Kode Event-Rodeh Codes.

4. Menghitung bit dan pengurutan berdasarkan kode Even-Rodeh Codes

5. Pengelompokan string bit.

6. Hasil dikompresi.

Dibawah ini adalah tahap membangun kode Even-Rodeh Code dengan $n$ sebagai indeks dari karakter yaitu sebagai berikut[1]:

1. Menghitung panjang bit.

2. Jika panjang bit $0<=\mathrm{n}<=3$ jadi nilai $\mathrm{n}$ dirubah ke dalam biner, dengan menambahkan 0 tepat didepan nilai biner sehingga bit menjadi 3 digit.

3. Jika panjang bit $4<=\mathrm{n}<=7$ jadi nilai $\mathrm{n}$ dirubah ke dalam biner, dengan menambahkan 0 tepat dibelakang nilai biner sehingga bit menjadi 4 digit.

4. Jika panjang bit $\mathrm{n}>=8$ jadi nilai $\mathrm{n}$ dirubah ke dalam biner,dengan menambahkan 0 tepat dibelakang nilai biner kemudian angka ditambahkan didepan nilai biner sebanyak jumlah digit nilai dalam biner.

Beriku ini adalah urutan kode Even-Rodeh Code dan jumlah bit berdasarkan nilai $n$ dari panjang karakter bisa dilihat pada tabel 2.1[5].

Tabel 1. kode Algoritma Omega dan Algoritma Even-Rode Codes

\begin{tabular}{cl}
\hline $\mathrm{N}$ & Even-Rodeh Code \\
\hline 0 & 000 \\
1 & 001 \\
2 & 010 \\
3 & 011 \\
4 & 1000 \\
7 & 1110 \\
8 & 10010000 \\
15 & 10011110 \\
16 & 100100000 \\
32 & 1101000000 \\
100 & 11111001000 \\
1000 & 11011001000 \\
\hline
\end{tabular}

.Beriku ini adalah kode Even-Rodeh Code berdasarkan variasi karakter[5]. dapat dilihat pada tabel 2.2 diberikut ini.

Tabel 2. Kode Even-Rodeh dari variasi karakter

\begin{tabular}{cc}
\hline $\mathrm{N}$ & Jumlah bit Even-Rodeh Code \\
\hline 1 & 3 \\
$2-3$ & 3 \\
$4-7$ & 4 \\
$8-15$ & 8 \\
$16-31$ & 9 \\
$32-63$ & 10 \\
$64-127$ & 11 \\
$128-255$ & 17 \\
$256-512$ & 18 \\
\hline
\end{tabular}

\subsection{Citra atau Gambar}

Citra atau gambar adalah alat yang manusia pakai untuk menyampaikan pesan kepada manusia lainnya. Citra merupakan pengambungan antara titik, garis, bidang, dan warna untuk menghasilkan suatu ilustrasi dan suatu obyek seperti, obyek fisik atau obyek manusia[4]. Citra (image) merupakan komponen yang sanggat penting untuk menyampaikan pesan secara obyektif dengan cara memvisualkan melalui alat multimedia yang digunakan dan citra (image) sanggat berbeda dengan data-data lainnya seperti data text[2].

\section{ANALISA DAN PEMBAHASAN}

\subsection{Pembahasan}


Dalam melakukan kompresi file gambar sebelumnya harus dilakukan analisa terhadap file gambar yang akan dikompresi. Dalam menganalisa file gambar harus dilakukan mengambilan sample file gambar untuk mendapatkan nilai dari pixel-nya. Berikut adalah langkah untuk mengkompresi dan mendekompresi file gambar.

Melakukan analisa proses kompresi file gambar mengunakan algoritma Even-Rodeh Codes

1. Input file gambar

Melakukan kompresi pada file gambar adalah terlebih dahulu harus memasukan file gambar. File gambar yang digunakan untuk dikompresi dalam penelitian ini adalah berukuran 50 x 70 pixel.

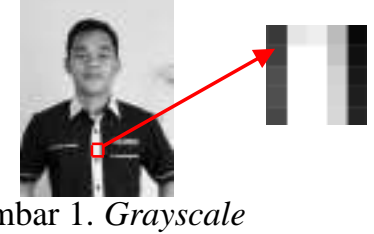

Berdasarkan gambar diatas maka dapat dianalisa bahwa dalam proses kompresi file gambar dapat diambil sample gambar dengan ukuran 5 x 5 pixel, dengan tujuan untuk menggetahui cara kerja kompresi mengunakan algoritma Even-Rodeh Codes dan untuk menghemat waktu peneliti dalam kompresi file gambar, berikut ini adalah sample dari gambar yang akan dikompresi:

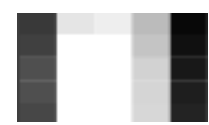

Gambar 2. Sample gambar 5 x 5 yang akan dikompresi

2. Membaca nilai pikxel dan kemunculan frekuensi

Langkah selanjutnya adalah dengan melakukan pembacaan isi file gambar. Setiap Isi file gambar terdapat nilai pixel. Nilai pixel tersebut diproses dalam bentuk 5 x 5 sehingga menghasilkan 25 pixel sebagai sample gambar yang akan dianalisa. Adapun nilai 25 pixel gambar tersebut dapat dilihat pada gambarl di bawah ini :

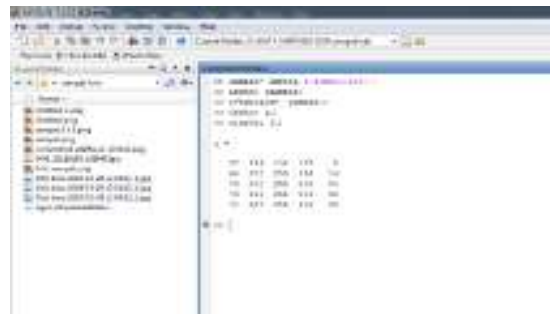

Gambar 3. nilai 25 pixel sample

Berikut ini adalah hasil pengambilan sample gambar yang akan dikompresi berdasarkan dari nilai 25 pixel akan ditunjukan pada Tabel 3.1 berikut ini :

Tabel 3. Nilai 25 titik pixel

\begin{tabular}{llllc}
\hline 57 & 229 & 238 & 187 & 8 \\
64 & 255 & 255 & 196 & 16 \\
79 & 255 & 255 & 210 & 24 \\
79 & 255 & 255 & 213 & 30 \\
71 & 255 & 255 & 215 & 35 \\
\hline
\end{tabular}

Berdasarkan pada Tabel di atas, terdapat nilai pixel file gambar sample. Untuk keperluan hitungan manual hanya diambil sample nilai sebanyak 25 karakter dari nilai pixel file gambar sample. Adapun nilai pixel file gambar sample tersebut adalah 57, 229, 238, 187, 8, 64, 255, 255, 196, 16, 79, 255, 255, 210, 24, 79, 255, 255, $213,30,71,255,255,215,35$. Selanjutnya adalah akan dilakukan pengelompokan nilai pixel berdasarkan nilai frekuensi. Urutan karakter nilai pixel dapat dilihat pada tabel berikut ini:

\begin{tabular}{cc} 
Tabel 4. Pembacaan Nilai Pixel dan frekuensi \\
\hline Pixel & Frek \\
\hline 255 & 8 \\
79 & 2 \\
8 & 1 \\
16 & 1 \\
24 & 1 \\
30 & 1
\end{tabular}




\begin{tabular}{cc}
35 & 1 \\
57 & 1 \\
64 & 1 \\
71 & 1 \\
187 & 1 \\
196 & 1 \\
210 & 1 \\
213 & 1 \\
215 & 1 \\
229 & 1 \\
238 & 1 \\
\hline Total Pixel & 25 \\
\hline
\end{tabular}

Berdasarkan pada tabel di atas, didapatkan beberapa nilai pixel yang sama. Sebelum proses kompresi citra, langkah awal adalah membaca nilai pixel citra kemudian membuat tabel nilai pixel yang diurutkan dari nilai frekuensi terbesar (nilai pixel yang sama) ke terkecil. Urutan nilai pixel dapat dilihat pada tabel di bawah ini :

\begin{tabular}{ccccc}
\multicolumn{5}{c}{ Tabel 5. Pixel yang Belum Dikompresi } \\
\hline pixel & Nilai & \multirow{2}{*}{ bit } & Frek & Bit x \\
Frek
\end{tabular}

Berdasarkan tabel di atas, satu nilai pixel desimal (karakter) bernilai delapan bit bilangan biner. Sehingga 25 titik pixel mempunyai nilai biner sebanyak 200 bit. Setelah di dapat nilai bit dari semua nilai pixel.

3. Pembentuk kode Even-Rodeh Codes

Proses pengkompresian ini menggunakan algoritma Even-Rodeh Codes. Pengkompresian dilakukan dengan mengalikan nilai frekuensi desimall dengan nilai frekuensi bit dari Even-Rodeh Codes. Aturan dalam pembentukan kode bilangan dengan menggunakan Even-Rodeh Codes dapat dilihat pada landasan teori pada bab sebelumnya . Adapun nilai dari Even-Rodeh Codes dapat dilihat pada tabel berikut:

\begin{tabular}{cl}
\multicolumn{2}{c}{ Tabel } \\
\hline$N$ & \multicolumn{1}{c}{ Even-Rodeh Codes } \\
\hline 0 & 000 \\
1 & 001 \\
2 & 010 \\
3 & 011 \\
4 & 1000 \\
7 & 1110 \\
8 & 10010000 \\
15 & 10011110 \\
16 & 100100000 \\
32 & 1101000000
\end{tabular}




\begin{tabular}{cc}
100 & 11111001000 \\
1000 & 11011001000 \\
\hline
\end{tabular}

4. Menghitung bit gambar dan pengurutan kode Even-Rodeh Codes serta memperoleh bit file terkompresi. Proses kompresi ini adalah melakukan kompresi nilai dari citra pixel sampel dengan nilai kode Even-Rodeh yang di dapat dari tabel 3.4 di atas. Adapun Proses kompresi citra sampel dapat dilihat pada tabel di bawah ini :

Tabel 7. pixel Sampel Dikompresi Dengan Nilai Even-Rodeh

\begin{tabular}{cccccc}
\hline N & Nilai Dec Pixel & Even-Rodeh & Bit & Frek & Bit x Frek \\
\hline 0 & 255 & 000 & 3 & 0 & 255 \\
1 & 79 & 001 & 3 & 1 & 79 \\
2 & 8 & 010 & 3 & 1 & 3 \\
3 & 16 & 011 & 3 & 1 & 3 \\
4 & 24 & 1000 & 4 & 1 & 4 \\
5 & 30 & 1010 & 4 & 1 & 4 \\
6 & 35 & 1100 & 4 & 1 & 4 \\
7 & 57 & 1110 & 4 & 1 & 4 \\
8 & 64 & 10010000 & 8 & 1 & 8 \\
9 & 71 & 10010010 & 8 & 1 & 8 \\
10 & 187 & 10010100 & 8 & 1 & 8 \\
11 & 196 & 10010110 & 8 & 1 & 8 \\
12 & 210 & 10011000 & 8 & 1 & 8 \\
13 & 213 & 10011010 & 8 & 1 & 8 \\
14 & 215 & 10011100 & 8 & 1 & 8 \\
15 & 229 & 10011110 & 8 & 1 & 8 \\
16 & 238 & 100100000 & 9 & 1 & 9 \\
\hline
\end{tabular}

Berdasarkan pada tabel di atas dapat dibentuk nilai bit baru hasil kompresi dari susunan nilai desimal pixel sampel sebelum dikompresi yaitu 57, 229, 238, 187, 8, 64, 255, 255, 196, 16, 79, 255, 255, 210, 24, 79, 255, $255,213,30,71,255,255,215,35$ (tanpa ada tanda koma dan spasi).

5. Menperoleh string bit dan penambahan padding dan flag.

Proses ini adalah merubah nilai pixel menjadi string bit nilai biner seperti berikut ini.

“1110100111101001000001001010001010010000000000100101100110010000001001100010000010000001 $0011010101010010010000000100111001100 "$ ". Terlebih dahulu dilakukan penambahan bit padding dan flag sebelum hasil dari kompresi dituliskan ke dalam file. Penambahan pada bit padding dan flag bit dilakukan dengan mengacu pada sisa jumlah bit dibagi 8. Jumlah dari hasil kompresi adalah 125 bit, karena 125 tidak habis dibagi 8 maka dapat diperoleh padding bentuk bit yaitu "000" agar habis dibagi 8. Dengan demikian, flag bits yang merupakan nilai biner dari panjang padding bit yaitu 3 dalam biner menjadi "00000011". Sehingga string bit yang terbentuk adalah :

11101001111010010000010010100010100100000000001001011001100100000010011000100000100000010 01101010101001001000000010011100110000000000011".

Agar pada saat proses dekompresi agar dapat diketahui bahwa dimensi dari citra awal adalah $5 \times 5$ pixel maka akan ditambahkan string ",5,5” pada nilai biner karakter hasil kompresi. Karakter koma (,) yang pertama digunakan untuk memisahkan karakter hasil kompresi dengan karakter dimensi. Karakter "5" yang pertama digunakan unuk mengetahui nilai dari sumbu x yang terdapat pada citra awal. Karakter koma (,) yang kedua digunakan untuk memisahkan nilai sumbu x dengan nilai sumbu y pada citra awal. Karakter "5" yang kedua digunakan untuk mengetahui nilai dari sumbu y yang terdapat pada citra awal. Sehingga didapatkan nilai biner hasil kompresi citra setelah penambahan string biner dimensi citra ",5,5" (tanpa ada tanda petik) sebagai berikut :

11101001111010010000010010100010100100000000001001011001100100000010011000100000100000010 0110101010100100100000001001110011000000000001100101100000001010010110000000101.

Sehingga total bit sebelumnya setelah ditambahkan padding dan flag bits dan string dari dimensi ,5,5 adalah $125+3+8+32=168$ bit .

Langkah selanjutnya adalah pengelompokan string bit masing-masing terdiri dari 8 bit seperti gambar berikut ini:

\begin{tabular}{|llll|}
\hline 11101001 & 11101001 & 00000100 & 10100010 \\
10010000 & 00000010 & 01011001 & 10010000 \\
\hline
\end{tabular}




\begin{tabular}{|llll|}
\hline 00100110 & 00100000 & 10000001 & 00110101 \\
01010010 & 01000000 & 01001110 & 01100000 \\
$\mathbf{0 0 0 0 0 0 1 1}$ & $\mathbf{0 0 1 0 1 1 0 0}$ & $\mathbf{0 0 0 0 0 1 0 1}$ & $\mathbf{0 0 1 0 1 1 0 0}$ \\
$\mathbf{0 0 0 0 0 1 0 1}$ & & & \\
\hline
\end{tabular}

Gambar 4. Nilai biner Terkompresi

Selanjutnya untuk mendapatkan hasil citra gambar terkompresi maka bit yang telah di susun 8 digit diubah ke decimal dengan menggunakan kode ASCII untuk megetahui nilai dari pixel yang sudah terkompresi. Adapun nilai decimal tersebut adalah sebagai berikut:

Tabel 8. Nilai desimal Terkompresi

\begin{tabular}{cccc}
\hline $\begin{array}{c}\text { Urutan } \\
\text { Pixel } \\
\text { terkompresi }\end{array}$ & $\begin{array}{c}\text { Nilai } \\
\text { desimal } \\
\text { terkompresi }\end{array}$ & $\begin{array}{c}\text { Urutan } \\
\text { Pixel } \\
\text { terkompresi }\end{array}$ & $\begin{array}{c}\text { Nilai } \\
\text { desimal } \\
\text { terkompresi }\end{array}$ \\
\hline 1 & 233 & 12 & 53 \\
2 & 233 & 13 & 82 \\
3 & 4 & 14 & 64 \\
4 & 162 & 15 & 78 \\
5 & 144 & 16 & 96 \\
6 & 2 & 17 & 3 \\
7 & 89 & 18 & 44 \\
8 & 144 & 19 & 5 \\
9 & 38 & 20 & 44 \\
10 & 32 & 21 & 5 \\
11 & 129 & &
\end{tabular}

Karakter yang dihasilkan dari kompresi diatas tersimpan dalam suatu file yang berbentuk ekstensi "edc", dan jika file tersebut dibuka mengunakan notepad akan tampil karakter seperti dibawah ini :

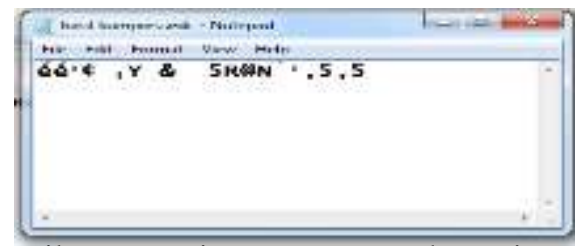

Gambar 5. Hasil Kompresi Dengan Penamban Dimensi Citra Awal

Ratio of Compression $\left(\mathrm{R}_{\mathrm{C}}\right)$

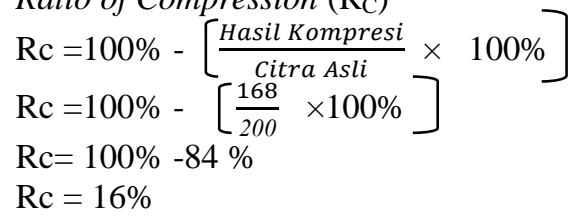

Adapun proses dekompresi file gambar menggunakan algoritma Even-Rodeh Codes adapun proses dekompresi tersebut sebagai berikut:

1. File gambar hasil kompresi

Berdasarkan dari hasil kompresi gambar dengan penambahan string dimensi biner yang didapati sebelumnya adalah sebagai berikut:

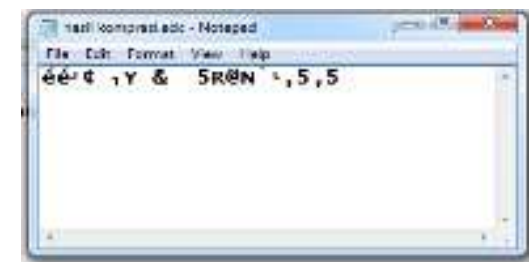

Gambar 6. Hasil file Gambar kompresi sebelumnya

proses dekompresi hal yang dilakukan adalah mencari sebuah informasi dimensi dari citra awal dengan cara mengambil karakter yang terdapat pada hasil file kompresi sebelumnya, penambahan karakter dimensi tersebut adalah “,5,5"(tanpa tada petik dua di atas) yang dimana koma(,) pertama untuk memisahkan hasil kompresi. Karakter pertama hasil File kompresi yaitu 5 menandakan itu adalah sumbu y pada citra awal. Karakter kedua hasil file kompresi yaitu koma(,) yang dimana koma adalah pemisa dari sumbu y dan x. Karakter ketiga yang terdapat diakhir isi file hasil kompresi yaitu " 5 " yang menandakan itu adalah sumbu x pada citra awal. Makah 
sudah diketahui bahwa dimensi dari citra awal adalah $5 \times 5$ pixel. Setelah ditemukan dimensi citra awal dari proses pengenalan nilai bener di atas maka nilai karakter biner dimensi citra tersebut dihilangkan.

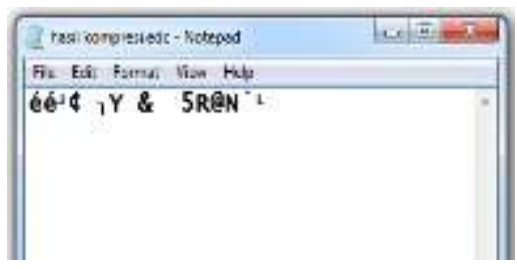

Gambar 7. Hasil karakter kompresi

Selanjutnya menganalisa keseluruhan bit hasil dari kompresi sebelumnya dan mencari dimensi gamnbar. Adapun bit keseluruhan hasil kompresi sebelumnya dapat dilihat pada tabel berikut :

Tabel 9. Nilai biner dan desimal pixel sampel dari hasil kompresi

\begin{tabular}{ccccc}
\hline Biner & 11101001 & 11101001 & 00000100 & 10100010 \\
\hline Desimal & 233 & 233 & 4 & 162 \\
Biner & 10010000 & 00000010 & 01011001 & 10010000 \\
Desimal & 144 & 2 & 89 & 144 \\
Biner & 00100110 & 00100000 & 10000001 & 00110101 \\
Desimal & 38 & 32 & 129 & 53 \\
Biner & 01010010 & 01000000 & 01001110 & 01100000 \\
Desimal & 82 & 64 & 78 & 96 \\
Biner & $\mathbf{0 0 0 0 0 0 1 1}$ & & & \\
Desimal & 3 & & & \\
\hline
\end{tabular}

Berdasarkan pada tabel di atas maka diambil seluruh nilai biner dan digabungkan menjadi:

“11101001111010010000010010100010100100000000001001011001100100000001001100010000010000001 0011010101010010010000000100111001100000 00000011"

2. Pengurangan bit akhir ke string semula

Proses ini adalah dengan mengembalikan binary menjadi string bit semula hilangkan biner yang ditebalkan di atas. Untuk mengembalikan binary menjadi string bit semula dapat dilakukan melalui langkah berikut ini. Lakukan pembacaan pada 8 bit terakhir dan pembacaan terhadap penambahan padding sebelumnya terdapat 3 bit, hasil pembacaan berupa bilangan desimal. Terdapat nilai biner 12 bit terakhir sebagai berikut, "000000000011" dalam desimal dilakukan pembacaan 8 bit terakhir adalah merupakan nilai 3. Sedangkan nilai 3 bit tersebut merupakan 3 buah nilai bit pada saat padding sebelum ditambahkanya flag bits. Hapus Flags bits dan Padding dari nilai keseluruhan bit sehingga menjadi seperti di bawah ini.

“11101001111010010000010010100010100100000000001001011001100100000001001100010000010000001001 $1010101010010010000000100111001100 "$

3. Menghitung bit sesuai dengan kode Even-Rodeh Codes dan proses dekompresi biner nilai pixel desimal.

Proses ini adalah melakukan cek bit dari bit pertama dengan tabel kode Even-Rodeh codes pada tabel 3.5 di atas. Jika ditemukan bit yang sesuai dengan tabel kode Even-rodeh codes di atas maka ubah nilai string yang sesuai. Sehingga didapati hasil seperti tabel di bawah ini :

\begin{tabular}{cc} 
Tabel 10. Hasil Dekompresi menggunakan & Even-Rodeh Codes \\
\hline Even-Rode Codes & Nilai Pixel \\
\hline 1110 & 57 \\
10011110 & 229 \\
100100000 & 238 \\
10010100 & 187 \\
010 & 8 \\
10010000 & 64 \\
000 & 255 \\
000 & 255 \\
10010110 & 196 \\
011 & 16 \\
001 & 79 \\
000 & 255 \\
000 & 255 \\
10011000 & 210 \\
1000 & 24
\end{tabular}




$\begin{array}{cc}001 & 79 \\ 000 & 255 \\ 000 & 255 \\ 10011010 & 213 \\ 1010 & 30 \\ 10010010 & 71 \\ 000 & 255 \\ 000 & 255 \\ 10011100 & 215 \\ 1100 & 35\end{array}$

Berdasarkan hasil dekompresi di atas didapati nilai awal pixel citra sampel 5 x 5 sehingga dihasilkan string semula seperti tabel di bawah.

Tabel 12. Nilai awal 25 titik pixel

\begin{tabular}{ccccc}
\hline 57 & 229 & 238 & 187 & 8 \\
\hline 64 & 255 & 255 & 196 & 16 \\
79 & 255 & 255 & 210 & 24 \\
79 & 255 & 255 & 213 & 30 \\
71 & 255 & 255 & 215 & 35 \\
\hline
\end{tabular}

Berdasarkan pada gambar di atas hasil dekompresi mengembalikan seluruh nilai pixel sampel sebanyak 25 pixel tanpa adanya perubahan nilai dari sebelum kompresi, selanjutnya nilai pixel tersebut dirubah menjadi sebuah gambar sesuai file gambar asli

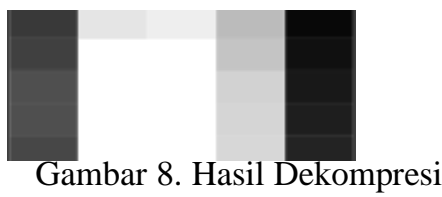

\section{IMPLEMENTASI}

Tampilan program merupakan tampilan dari aplikasi dengan penerapan algoritma even-rodeh pada aplikasi kompresi file gambar. Aplikasi ini dibuat dengan bebasis desktop. Aplikasi yang akan dijalankan telah dibangun dengan menggunakan aplikasi Microsoft Visual Studio 2008 dengan bahasa pemograman visual basic. Tampilan aplikasi program yang dibutuhkan diantaranya yaitu tampilan input dan tampilan output. Tampilan input tediri dari interface aplikasi, tampilan output terdiri dari hasil dari proses kompresi dan dekompresi. Tampilan Output merupakan tampilan proses ketika gambar yang akan kita dikompresi menampilan hasil kompresi serta proses dekompresi gambar. Adapun proses tersebut dapat dilihat pada gambar di bawah ini :

1. Memilih Gambar Kompresi

Memilih gambar kompresi dilakukan ketika user akan melakukan proses kompresi. Adapun proses pemilihan gambar dapat dilihar pada gambar 9.

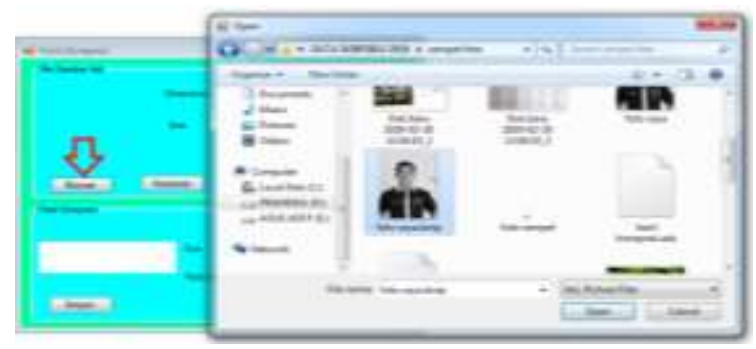

Gambar 9. Memilih Gambar Kompresi

Berdasarkan pada gambar 9. , proses yang harus dilakukan ketika pengguna (user) melakukan kompresi gambar adalah memilih tombol browse dimenu aplikasi kompresi. Tampilan direktori komputer akan terbuka dan user yang sudah memilih gambar dapat menekan tombol open, kemudian gambar yang dipilih akan tampil pada picturebox aplikasi, dapat dilihat pada gambar 10

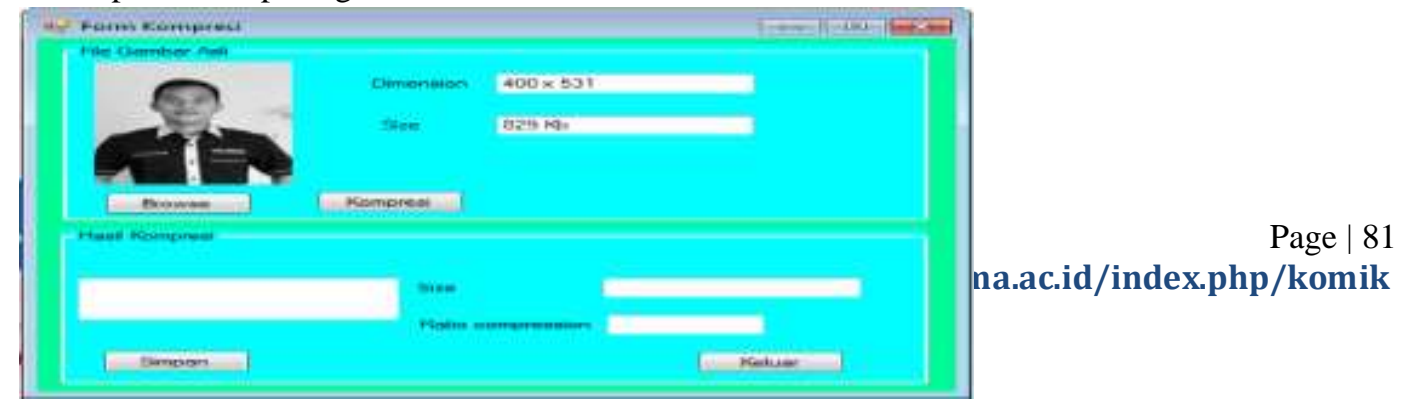


2. Tampilan Kompresi Gambar

Gambar 10. Tampilan Gambar Yang Terpilih

Tampilan kompresi gambar adalah form yang menampilkan hasil dari kompresi gambar berupa karakter. Ada tampilan hasil kompresi citra dapat dilihat pada gambar 11 di bawah ini.



Gambar 11. Tampilan Gambar Hasil Kompresi

3. Proses Penyimpanan Gambar Hasil Kompresi

Pada proses ini akan menampilkan output yang akan keluar ketika gambar hasil kompresi yang akan disimpan. Adapun tampilan simpan gambar hasil kompresi dapat dilihat pada gambar 4.8 di bawah ini :

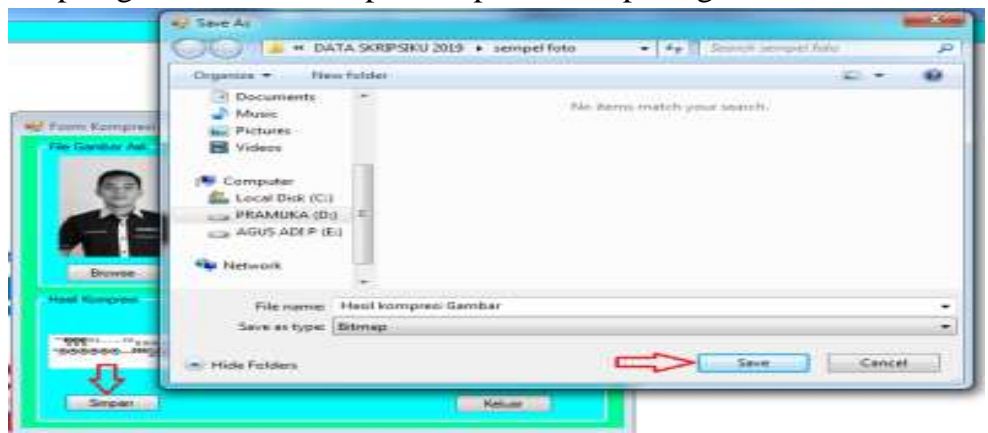

Gambar 12. Tampilan Simpan Hasil Kompresi

4. Proses Memilih File Gambar yang akan didekompresi

Proses dekompresi adalah proses pengembalian ukuran gambar pada ukuran semula sebelum kompresi. Proses penginputan gambar dilakukan dengan cara yang sama saat proses kompresi. Adapun proses memasukan file gambar terkompresi sebelumnya dapat dilihat pada gambar 13 di bawah ini :



Gambar 13. Tampilan Proses Dekompresi

Berdasarkan pada gambar diatas, proses yang harus dilakukan ketika pengguna (user) melakukan dekompresi gambar adalah memilih tombol browse dimenu aplikasi dekompresi. Tampilan direktori komputer akan terbuka dan user yang sudah memilih gambar dapat menekan tombol open. kemudian file gambar yang dipilih akan tampil pada textboox dalam bentuk karakter aplikasi, dapat dilihat pada gambar 14 .

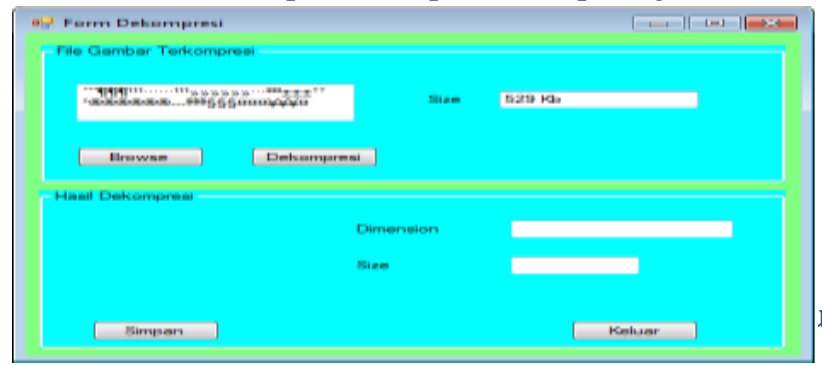




\section{Gambar 14. Tampilan File Gambar dekompresi}

5. Tampilan Dekompresi Gambar

Tampilan dekompresi gambar adalah form yang menampilkan hasil dari dekompresi karakter berupa gambar semula. Ada tampilan hasil kompresi gambar dapat dilihat pada gambar 4.11 di bawah ini.

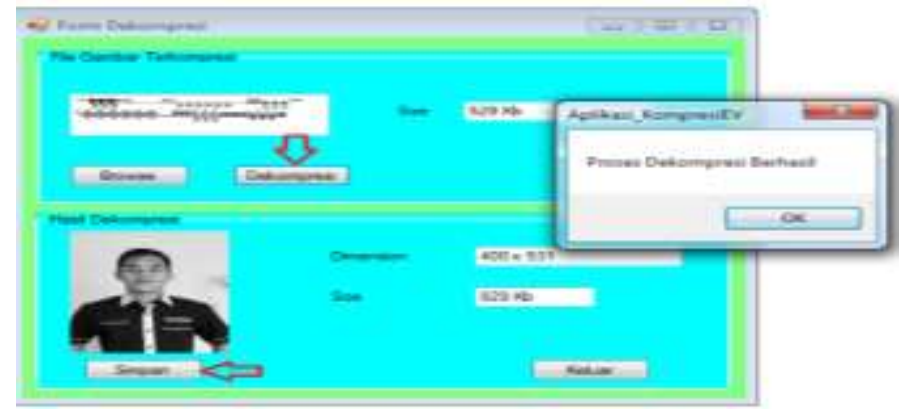

Gambar 15. Tampilan Dekompresi Gambar

Berdasarkan pada gambar diatas, proses dekompresi dimulai dengan memilih tombol dekompresi. Hasil dekompresi adalah gambar awal dengan ukuran dan dimensi yang kembali seperti semula pada saat dekompresi. Hasil gambar dekompresi dapat simpan dengan memilih tombol simpan.

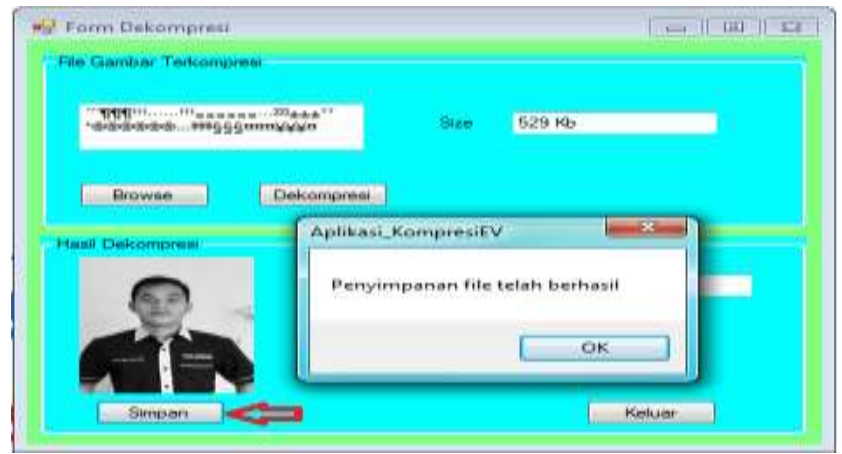

Gambar 16. Tampilan Proses Simpan

\subsection{Hasil Pengujian Sistem}

Pengujian sistem merupakan tahap mengidentifikasi hasil dari implementasi sistem aplikasi. Hasil pengujian terdiri dari hasil pengujian kompresi dan hasil pengujian dekompresi. Hasil pengujian berupa perbedaan antara gambar sebelum dan sesudah kompresi serta dekompresi.

1. Hasil Pengujian Kompresi Gambar

Adapun hasil pengujian dari gambar yang dilakukan kompresi dapat dilihat pada tabel di bawah ini :

Tabel 13. Hasil sebelum Pengujian Kompresi Gambar

\begin{tabular}{|c|c|c|c|c|c|c|}
\hline \multirow{2}{*}{ No } & \multicolumn{3}{|c|}{ Sebelum Kompresi } & \multicolumn{3}{|c|}{ Sesudah Kompresi } \\
\hline & Gambar & Dimensi & Ukuran & Nama File & Ukuran & $\mathrm{CR}$ \\
\hline \multicolumn{7}{|l|}{1} \\
\hline & & $400 \times 531$ & $829 \mathrm{~KB}$ & Foto saya.bmp & $529 \mathrm{~KB}$ & $70 \%$ \\
\hline 2 & & $640 \times 1280$ & $116 \mathrm{~KB}$ & Kompresi.edc & $58,7 \mathrm{~KB}$ & $65 \%$ \\
\hline
\end{tabular}


Berdasarkan pada hasil pengujian pada diatas, menunjukan bahwa hasil kompresi gamabar memiliki perbedaan ukuran dan dimensi ketika citra sebelum kompresi. Hal ini dapat dilihat dari berbeda hasil CR berdasarkan hasil pengujian.

2. Hasil Pengujian Dekompresi Gambar

Adapun hasil pengujian dekompresi dari gambar yang sudah dilakukan kompresi dapat dilhat pada tabel dibawah ini:

Tabel 14. Hasil Pengujian Dekompresi Gambar

\begin{tabular}{|c|c|c|c|c|c|}
\hline \multirow{2}{*}{ No } & \multicolumn{2}{|c|}{ Gambar Kompresi } & \multicolumn{3}{|c|}{ Sesudah Dekompresi } \\
\hline & Nama File & Ukuran & Gambar & Dimensi & Ukuran \\
\hline 1 & Foto saya.bmp & $529 \mathrm{~KB}$ & & $400 \times 531$ & $829 \mathrm{~KB}$ \\
\hline 2 & Kompresi.edc & $58,7 \mathrm{~KB}$ & & $640 \times 1280$ & $116 \mathrm{~KB}$ \\
\hline
\end{tabular}

Dari hasil pengujian yang terlihat pada tabel diatas, menunjukan bahwa hasil dekompresi mengembalikan ukuran dan dimensi gambar, menjadi ukuran awal sebelum dilakukannya kompresi.

\section{KESIMPULAN DAN SARAN}

Berdasarkan hasil dari analisa yang telah dilakukan, maka dapat diambil beberapa kesimpulan dari bab-bab sebelumnya. Adapun beberapa kesimpulan sebagai berikut.

1. Prosedur kompresi file gambar dengan menerapkan algoritma Even-Rodeh Codes telah berhasil melakukan proses kompresi yang sesuai dengan langkah-langkah untuk melakukan proses kompresi dan dekompresi. Sehingga proses kompresi bisa berjalan sesuai dengan teknik kompresi.

2. Berdasarkan penerapan algoritma Even-Rodeh Codes, dengan algoritma ini dapat diketahui bahwa suatu file gambar yang ukurannya besar dapat dikompresi menjadi ukuran kecil. Sehingga dapat menghemat ruang penyimpanan memori lebih sedikit.

3. Kompresi file gambar dapat dirancang dan dibangun dengan menggunakan bahasa pemograman Microsoft Visual Studio 2008, dengan menerapkan algoritma Even-Rodeh Codes sehingga bisa diharapkan untuk mempermudah mengkompresi file gambar.

\section{REFERENCES}

[1] M. A. \& D. R. Budiman, "On Using Goldbach G0 Codes and Even-Rodeh Codes for Text Compression," IOP Conf. Ser. Mater. Sci. Eng, no. 012062, pp. 0-5, 2017.

[2] J. Emitor et al., "Kompresi citra dengan menggunakan metode delta modulation," vol. 14, no. 01, pp. 1-12.

[3] Darma Putra, Pengolahan Citra Digital. Yogyakarta: ANDI OFFSET, 2010.

[4] C. Shannon and F. Metode, "ALGORITMA SHANNON-FANO," 2012.

[5] D. S. G. Motta, Handbook of Data Compression”, Previous e. London Dordrecht Heidelberg New York: Springer-Verlag London Limited, 2010. 